\title{
Examining Mapping as a Tool for Community Empowerment in the Context of Unplanned Settlements; A Case of Karachi, Pakistan
}

\author{
Noman Ahmed ${ }^{1}$ and Fariha Tahseen
}

Department of Architecture \& Planning at NED University of Engineering \& Technology in Karachi, Pakistan

\begin{abstract}
Ever since her independence in 1947, Pakistan has experienced unplanned urbanization and rapid growth of informal settlements at a rapid pace. The large cities such as Karachi have become vast sprawling urban regions with a large share of unplanned settlements. Low income and poor communities reside in such settlements due to absence of state provided or facilitated options. Many predicaments confront such settlements. Threats of eviction, deteriorating law and order situation, lack of essential amenities, absence of water and sanitation, extortion and bullying from local and non-local musclemen and feeble response of government agencies towards their development needs are some mentions. Preventing illegal land transactions, initiating rehabilitation programs or making compensations for poor communities who need to be relocated and providing technical assistance for various development works in under privileged settlements that claims or succeeds in achieving security of land entitlement from government are among core responsibilities of a state for its people. The paper investigates (through literature review, field surveys and interviews) (a) initiation and proliferation of informal settlements in Karachi besides documenting state's response and initiatives to overcome the ever growing demand for housing (b) causes and process of peri urban land invasion causing rapid densification at the peripheral boundaries of Karachi (c) impacts and outcomes of unregulated urbanization affecting poor communities who remain underprivileged and deprived of decent living conditions and (d) appraisal of community based mapping as a tool in initiating and supporting development works in less privileged areas for community empowerment. Mapping may use as a documentation tool to generate factual evidences related to land ownership/ utilization status, state input related to land supply and other related matters. The OPP*, under the leadership of its slain director Perween Rahman $^{* *}$ had a significant role to play in developing and extending this approach in low income locations in Karachi and beyond.

${ }^{*}$ Well reputed for working to benefit the less privileged communities

** Perween Rehman was an architect and specialist in community development work. She worked in low income settlements of Karachi and other parts of the region for over thirty years. She was assassinated on $13^{\text {th }}$ March 2013.
\end{abstract}

Key Words: Informal Settlements (katchi abadis), land grabbing, community empowerment, housing rights, mapping, infrastructure development

\section{Initiation and Proliferation of Unplanned Settlements}

Urbanization in the developing world, as an inevitable phenomenon, is growing at a fast pace. Development of peri urban areas in
Asian cities is often left behind by the pace of urbanization (UN Habitat, 200-, p 99). In UN Habitat Program definition, informal settlements are defined as: 'i) residential areas where a group of housing units has been constructed on land to which the occupants

${ }^{1}$ Corresponding author

(iD https://orcid.org/0000-0003-3139-4543

E-mail address: nomaniconn@gmail.com

DOI: http://doi.org/10.4038/bhumi.v5i2.28 
have no legal claim, or which they occupy illegally ii) unplanned settlements and areas where housing is not in compliance with current planning and building regulations'. Undeniably as an integral part of urban fabric these informal settlements are the visual expression of urban poverty which being rapidly developed lacks in proper structure, planning and services. Mostly found on city fringes, Informal or squatter settlements breed on lands of unclear ownership, large tracts of vacant state's land, agricultural land acquired from government through lease, public areas, graveyards or environmentally hazardous lands such as along railway tracks, rivers, canals, drains etc (Fig. 1 and Fig. 2).Social services like schools, hospitals, parks, open spaces, mosques, markets, banks are also scarce. Roads and streets are unpaved, diseases are common and there is a general disharmony.

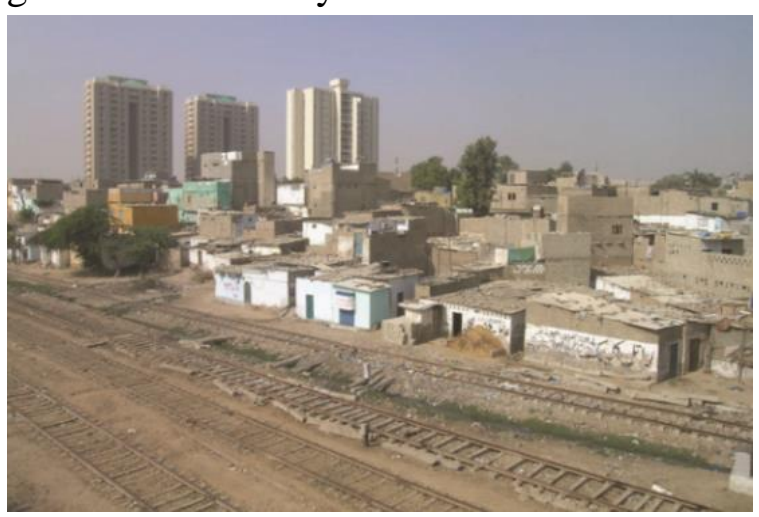

Figure 1: Informal settlement along railway lines (Source: URC, 2010)

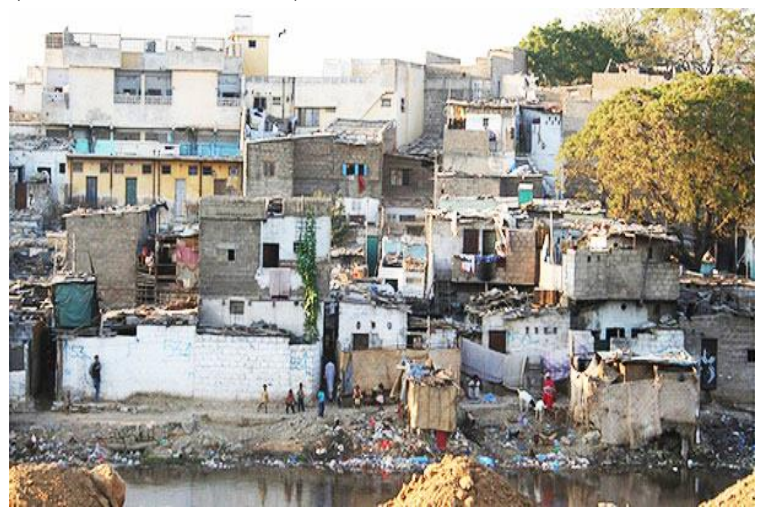

Figure 2: Informal settlement along drain (Source: Tahir Niaz, National newspaper, March 12, 2012)
Water and other essential services are acquired through informal means with higher than normal prices paid. In addition to being far distant from their work place, lack of easy access to public transportation is one of the greatest disadvantages to low income settlements sprawling in marginal areas of the city. Availability of and access to cheap land is one of the key factors which facilitates the proliferation of informal settlements in urban areas in developing countries (W.J. Kambe, 2005, p 122). The initial formation and proliferation of informal settlements in Pakistan, particularly Karachi, displayed similar patterns.

In Pakistan, the independence from the British colonial rule in 1947 was a major trigger to urbanization. Large influx of people from various parts of India caused cities such as Karachi to grow very fast. The city acquired a population of 1,050,000 in 1951 representing a two and a half fold increase since 1947 when the population was 435,000. An influx of 600,000 migrants from 1947 to 1951 transformed settlement status of the city. Initially government agencies allowed the poor refugees to settle temporarily in all available open lands or vacant buildings. As the building stock was in short supply, expansion of informal settlements became the option. In some cases, these settlements were evicted when built closer to prominent urban places. The temporary huts eventually became the shanty dwellings. Water supply and sanitation became core issues. City center became overly crowded and disregarded in quality of space and functions.

Later, the agricultural reforms introduced by the government made many semi-skilled and unskilled farm laborers unemployed in rural areas. Introduction of improved versions of 
seed and harvesting technologies and gradual replacement of manual and animal labor by mechanical farm equipment reduced the jobs. Additionally, creation of industries and business enterprises created a magnetic pull for people towards cities. Thus Karachi experienced a more than average national population growth rate throughout her postindependence existence. The government responded to this changing situation through plans, programs and projects, but they fell short of the scale of need. For instance, the ministry of rehabilitation decided to construct 45000 low cost houses every year since 1958 onwards. However it could not build more than 10,000 houses in five years. This scheme which was launched in Korangi neighborhood of Karachi had to be abandoned due to high capital cost. Other initiations in the form of site and services, open plot provisions and subsidized housing in different parts of the city could not address the physical scale and social need of housing. As a parallel, informal settlements continued to grow in different parts of the city. Mentioning the latest statistics of Karachi Strategic Development Plan 2020, Hasan (2008) informed that the housing demand is 80,000 units per year; building permits are issued for only 30,000 units, whereas 32,000 units are built informally, while the rest is accommodated through densification of existing settlements.

Initially the size of these settlements was small and spatial format haphazard disorganized, but soon the settlements learned from the planned neighborhoods. Informal land sub division, its dispersal and development became as planned settlements continued to expand in the peri urban locations of the city. This occupation of marginal lands is due to limited choices and construction affordability. Anwar (2013) stated; 'In subsequent decades the mounting and unmet demand for housing for low- and middle-income populations catalyzed the emergence of unplanned settlements that obeyed no scientific principles of planning. This was not a violation of planning edict but an adjunct to the state's plan. Thus the Karachi that was built as 'planned' grew in conjunction with the 'unplanned'. Orangi, Baldia, Qasba, Landhi and Korangi have large concentrations of unplanned informal settlements. In the absence of appropriate state support, residents in a sizeable number of these settlements survive in substandard conditions.

During 1980s, Katchi Abadis Improvement and Regularization Programme were launched by the Government. The programme recognized the fact that informal settlements are a reality and that organized state action is needed to improve the settlement conditions in different locations in the city. Promulgation of Sindh Katchi Abadis Authority Act 1987, creation of guiding principles for planning for regularization and formulations of an institution namely Sindh Katchi Abadis Authority (SKAA) were some outcomes of this approach. In the meantime, housing, as aptly illustrated by Mohammad Younus in the studies done by Urban the government also continued to follow some conventional approaches towards Resource Centre. Of the whole process a brief description in the form of diagram from the chronological account of the development schemes by government of Pakistan is listed below. 


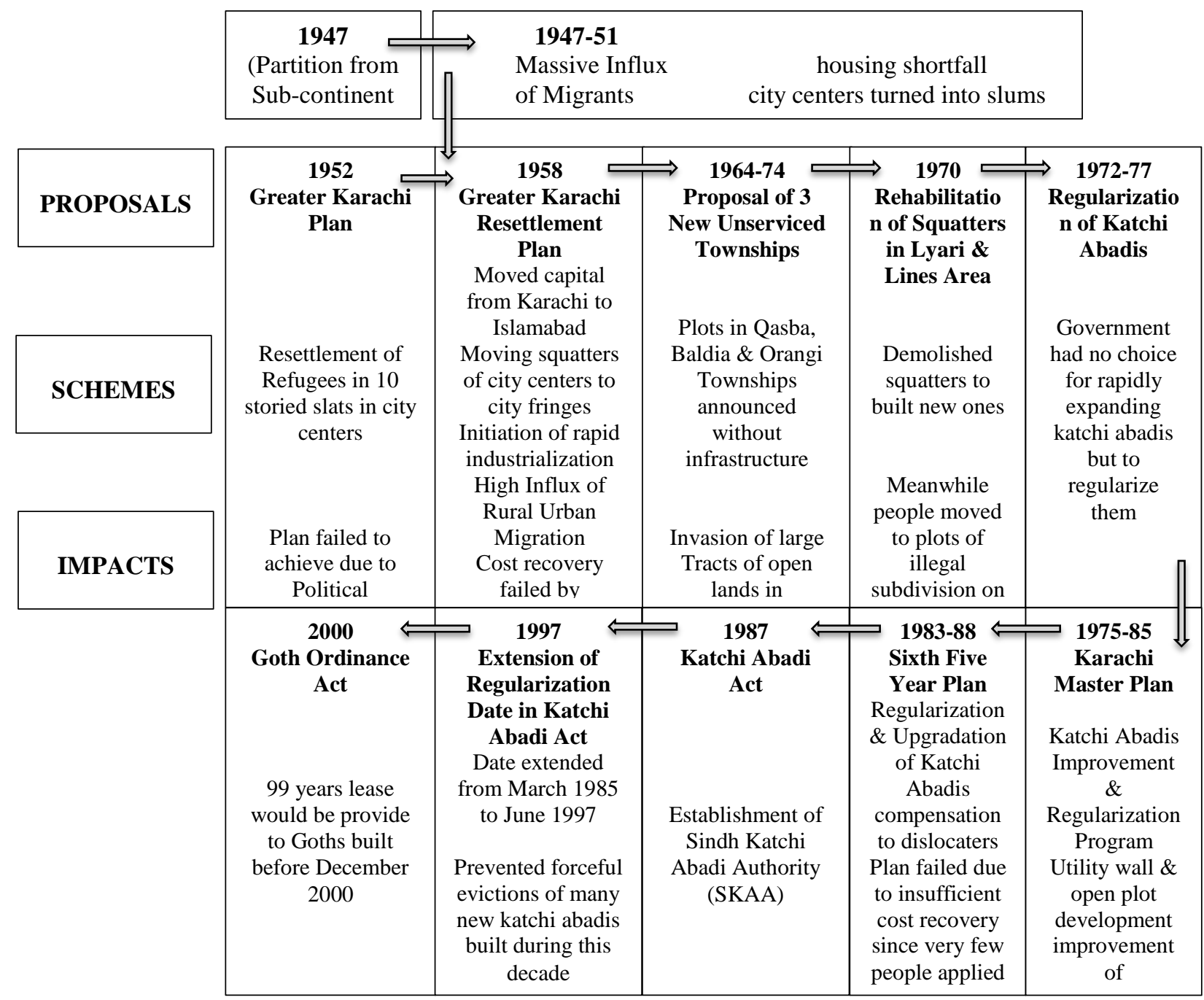

Figure 3: Overview of Initiation and development of Katchi Abadis in Karachi, Pakistan and Government Policies Schemes and their Impacts (Worked out by Authors from Hasan (2008), Anwar (2013) Younus (2010)

\section{Process of Land Invasion in Peri Urban Locations}

The process and agencies involved behind unplanned growth of informal settlements are the land brokers who illegally occupy a large tract of land in peripheral boundaries of urban districts in connivance with local police, government functionaries and co-operative housing societies. The land is subdivided into plots and sold to people under fake allotment papers and at nominal price due to being illegal, subserviced and far distant from city center. Hasan (2012) states; In the process, countless innocent citizens are deprived of their life savings in hopes of acquiring a home of their own. This dispossession of land at throwaway prices also robs the national exchequer of revenue. Land suppliers at one hand aware of state's failure in providing low cost housing to the urban poor and on the other hand knowing the desperately growing need of housing for low income communities perpetuated the ill legal market of land invasion and supply. The non-functioning legal and the flourishing illegal systems of land supply neatly complement each other and the government is much involved in both (Linden, Selier, 1991, p 362).

Development of three townships Baldia, Orangi and Qasba 1964-74 by the 
government, for the poor, drifted the city centre squatters to the city fringes. These townships, having no proper infrastructure, still pulled the unaffordable people which later being far distant from city centers starved for employment opportunities and basic facilities of transportation, health, education etc. In the proposed schemes of new townships the areas left vacant purposely for public amenities like schools, parks, dispensaries and markets remained barren and later encroached by informal land developers. In addition to this, large tract of vacant barren land in close vicinity of new townships became easily accessible for illegal subdivisions. Younus (2010) stated; 'The plot township of Orangi consisted of 1300 acres divided into plots. However, to the north-west of this area, illegal sub dividers have developed an additional 6000 acres consisting of over 60,000 plots'. Indeed, the informal settlements in west Karachi, with a population of over 1.2 million, were developed because of these three townships. Karachi is now having 61\% of population living in informal settlements which according to City District Government (2007) are unofficially created on state's land including parts of some 1200 villages existing on city fringes which became areas of rapid urban sprawl. 'In percentage terms, katchi abadis are gradually decreasing as very little government land is left to be encroached upon. There are said to be 539 katchi abadis in Karachi (some unofficial estimates put the figure at 702)' (SKAA Progress Report, 2003).

The illegal land transactions is becoming critically alarming and wide spread due to administrative loop holes by land managing authorities, weak law enforcement, involvement of government functionaries and political bodies who exploit their position of power for the sake of personal gains which increases violence and disharmony among the poor communities.

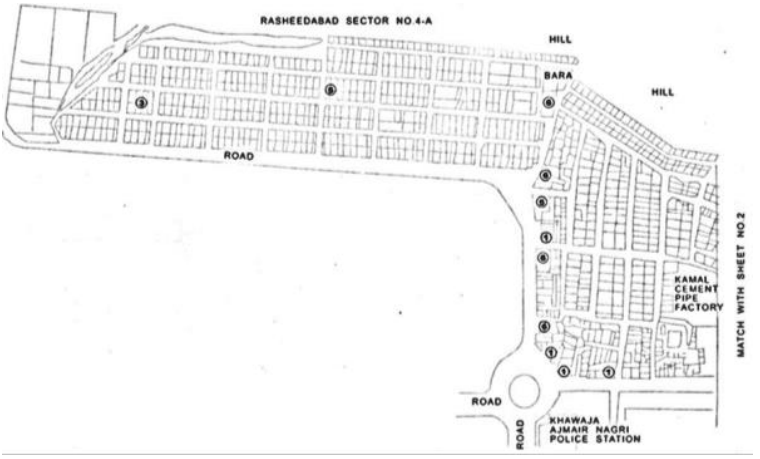

Figure 4: Map of Khwaja Ajmer Colony (Source: OPP-RTI, 2002)

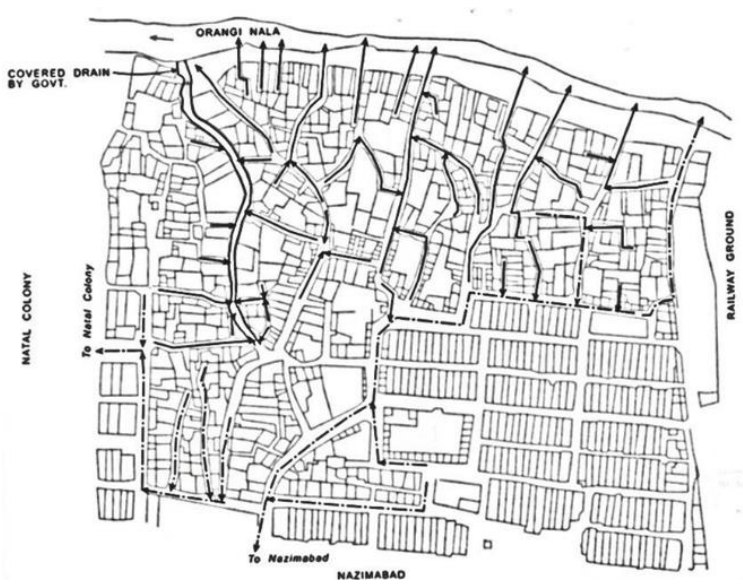

Figure 5: Map of Chota Maidan Colony (Source: OPP-RTI, 2002)

Informed by OPP director Salim Aleemuddin, a number of cases observed during the field survey of mapping and documenting the katchi abadis where besides encroachment by the people political and official bodies were also found to be involved in subdivision of large tracts of land around the informal settlements which initially resided along open drains (natural or laid by Govt.). An example to this was found in the map of a colony (Fig. 4 and Fig. 5) in which large tract of land subdivided in an organized and regular pattern along existing settlement which initiated in an unorganized pattern. 
In recent times, land supplying took a shift towards Goths (natural settlements or traditional villages). Goths on peri urban lands of the city are becoming part of rapid urban sprawl as they are less densified and close to the city therefore attractive for land developers. 'OPP-RTI research shows that out of the 2,173 goths, mostly in the three peripheral towns of Karachi (Gadap, Bin Qasim, Kemari), 1,146 goths (as per recent figures) have become urban settlements, (with fast subdivision of agricultural landmostly since 2006 onwards)' (137th QPR, 2014).

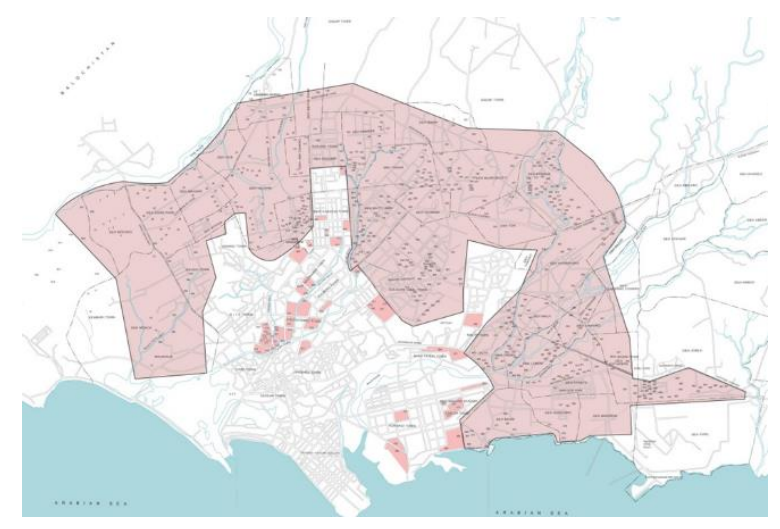

Figure 6: Map of Karachi Showing the Peripheral Urbanized Areas Needing Urban Development (Where 593 Goths out of 2173 Goths Have Become Abadis and 60 Goths already exist in Urban Areas) (Source: OPP-RTI, 2011)

Perween Rahman (Ismail, 2009) mentioned the fact of exponentially increasing land value in Karachi due to explosive growth in population and densely crowded city centers with a shift of urban development towards peripheral areas for which the city government and development authorities are targeting 'Goths' for eviction in order to reshape the city periphery and merge with the city under the control of City District Government Karachi (CDGK).

In addition to this during the last decade, Goth elders or land lords of several villages also started forceful eviction of the poor native settlers of the area for unjustified land subdivision and selling off to new purchasers of lower or middle income group. She also informed this kind of land subdivision is entirely unofficial but highly organized.

After getting the plots people built boundary walls along their plots as they would lose their land by reselling of their plot if unattended for two months. Fast construction on the plots is assisted through yards of building manufacturing blocks locally termed as thallas; commonly found everywhere. Other services of water, gas and electricity supply with an additional cost can be accessed through collaboration with local politicians.

In an interview to a journalist in September 2011, Perween Rahman discussed land, politics and violence in Karachi and explained the process of land grabbing. She informed there are four types of land suppliers. First, the elder of a Goth takes lease for some years on a large tract of land for agricultural purposes. Having the official document of lease he uses it as a document of ownership. He subdivides the land into plots and sells to a developer who is a middle man. In this ways Goths get populated and later acquire infrastructure facilities in alliance with affluent officials. The second way is through hiring an experienced land supplier who is in this process since ages. He subdivides the land and sales the plots by keeping a standard amount of share of money. The third category is of very experienced land suppliers and a bit dangerous. They buy some portion of land that is unofficial. Since they know the legal fact about only having permission of use, not the ownership rights therefore on this ground, they buy some portion of land at a negotiable price and promises to pay rest of the money after getting the land. But they never pay the remaining sum of money and also occupy 
remaining land with their group of armed persons. In this way they buy some area of land and occupy the rest. In Karachi Ettihad Town and Mohammad Khan Town with huge area around 3000 acres are nominal examples of land occupation and subdivision in this way. The fourth category is more dangerous since the people are members of political parties backed by political support. She mentioned eviction of people from two Goths in UC 8 of Gadap Town who were the native settlers. Their houses were demolished and resettled as Altaf Nagar occupying an area of 2500 acres being supported by the political party in power at that time. Initially started as welfare project; later became a business project. Land sub-divided into plots was sold with $\mathrm{KMC}^{2}$ stamps. Action of evicting the neighboring Goths also took place by the same Government for implementation of a scheme within 'Karachi Strategic Plan' 2020 which was accepted by all official bodies regardless of providing resettlement plan for those who had to be evicted from these Goths. Due to this eviction by the government, other Goths also felt threat. An illegal trait of unofficial land selling by Goth elders and land grabbing by influential developers started in and around the Goths.

\section{Social Exclusion and Forced Evictions}

Being underprivileged the communities of informal settlements are stressed for having low household incomes, lack of basic services and threat of eviction having insecure or unclear tenure of land. Younus (2010) stated about misappropriation of land by official bodies such as Katchi Abadis Regularization and Improvement Program for the 6th Five Years Plan Period of 19831988; 'Government surveyors make incorrect plans showing open areas as housing so that people can be settled there and money can be recovered from them. Alternatively, houses are shown as open areas and are subsequently bulldozed because they do not exist on the plan. The bulldozed area is then taken over by developers'. Katchi Abadi Act of 1987 declared regularization right to only those settlements established before 23 March 1985. The date of this act remained unamend till 2000 due to which many informal settlements faced forceful evictions several times. It was 2006 when OPP lobbied with Government functionaries for extension of this date up to 2006 but after partially successful negotiation acquired an extended date up to $30^{\text {th }}$ Jun 1997. Another Goth specific ordinance extends the cutoff date for provision of the 99 year lease to Dec'31st 2000 (OPP-RTI, 2014). In the name of development works, forced evictions take place without compensation or resettlement program for dislocates. Activity report of Urban Resource Center 2002 stated; 'the surveys show that in Karachi evictions take place in the most brutal way. The government agencies displace poor families overnight without any prior notices, compensations and/or alternatives. After eviction the poor families do not only lose their houses but also livelihoods, education of their children and neighborhood environment built over the years'. An example to this inhuman action was revitalization of Karachi's Circular Railway line. Being important for the city of 14 million people in a desperate need for any rail-based or rapid mass transit system did not account for resettlement of 6000 families living along the railways tracks. Past experience makes the railway communities suspicious that the project will be used as a pretext to grab their land for more lucrative

\footnotetext{
${ }^{2}$ Karachi Metropolitan Cooperation
} 
purposes or to harass poor communities for bribes (Younus, 2009).

\section{Constraints of Informal Sector Communities}

The core issues of informal settlements where they need technical assistance are;

a. Security of land tenure: high values of land, poverty and complicated legal procedures deprive the poor from acquiring an affordable house having legal protection. Buying a plot, in a recently initiated settlement through informal means, at nominal price also has greater value for not affording. The informal settlements being unidentified in city development plans of Government, thus remain on continuous threat of eviction once spotted and people may lose their life savings.

b. Lack of Social Services and Public Amenities: being informal and illegal the communities are deprived of basic services thus have an inadequate access to water supply, sewage and drainage, garbage disposal, paved streets and roads, lighting and electricity supply, public transport, education, entertainment, health and safety.

c. Economic Constraints: cost of purchasing a plot, constructing houses and conventional cost of providing sanitation and water supply by local official bodies is beyond affordability range of the poor.

d. Lack of Technical skills: People do not have technical skills for constructing sewerage lines and clean water supply pipes on self-help basis. Same is the case for other necessary services too.

e. Unawareness of legal rights and access to Government: unaware of their legal rights and proceedings about state's responsibilities for providing affordable and adequate housing to its residents, informal communities have negligible or no participation in government thus remain deprive of basic services, registration and infrastructure.

\section{Need for Technical Assistance; Mapping as a Tool for Community Empowerment}

To resolve above mentioned constraints, in 1992, OPP started documenting katchi abadis through mapping the existing conditions so as to achieve a framework of existing condition and to carry further development works. 'As there is no master plan and no proper survey, it is sometimes difficult to relate an economical slope for the line to the geography of the land' (Hassan, 1986, p 9). OPP during identification of katchi abadis found a lot of work done by the communities on sanitation and water supply through self-initiatives. This is the phenomenon of urbanization, people aspire for a higher standard, when government agencies do not respond and people organize to solve their problems themselves (OPPRTI, 2002, p 2). OPP realized the need to document this effort by the people and worked as a communication bridge between the government authorities, municipalities and dwellers of squatter settlements. 'Need was felt to document it, so as to a) understand the extent of community initiatives b) avoid duplication of work by government c) enable people to realize the extent of their own work, so as to strengthen their organization and 
efforts and d) be able to inform government's policy of the ground reality so as to compliment it' (OPP-RTI, 2002, p 2). Therefore, documentation through graphical representation of development works by the people and the government on sewerage, water supply lines, clinics, schools and thallas enabled to further extend the development works by the people in partnership with municipalities.

Three volumes documenting 300 katchi abadis out of 536 katchi abadis in Karachi by OPP-RTI is a productive demonstration of mapping. The format of these maps is based on graphical representation of location and statistics of each katchi abadi with a mention of total lanes, houses, population, area and documentation of internal development by people efforts and external development by government for sewerage lines, drains, nalas, water supply lines, clinics, schools and thallas.

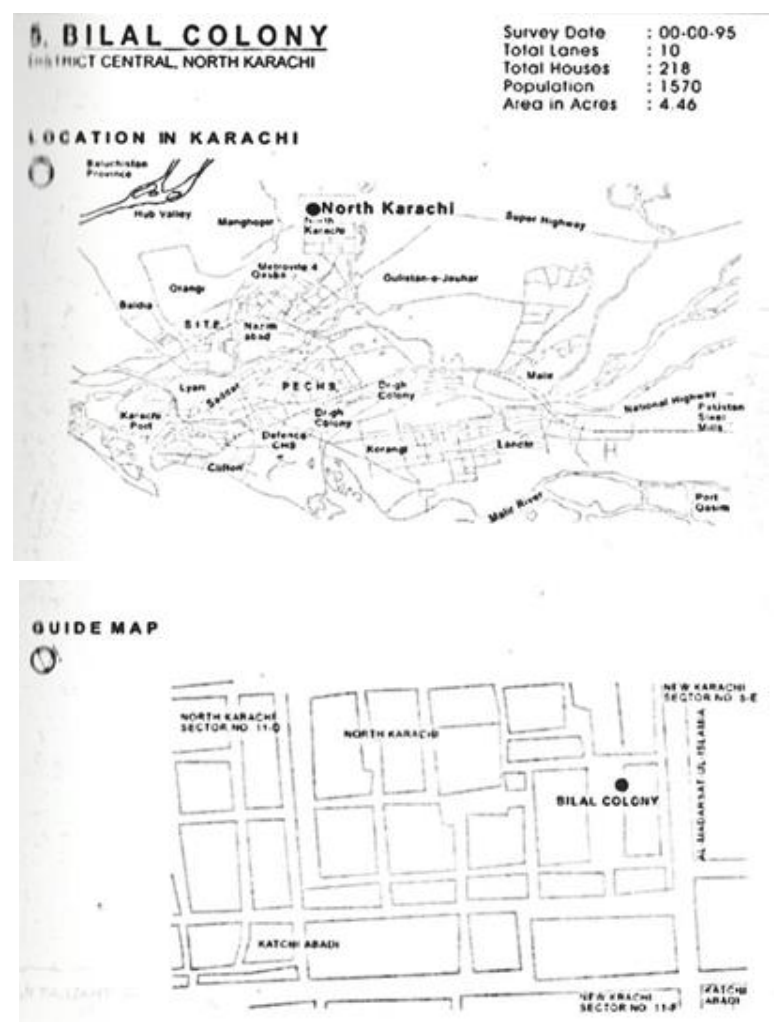

Figure 7 (a,b): Key Location maps of Bilal Colony (Source: OPP-RTI, 2002)
Review of the maps also outline the growth pattern of the squatter settlements; organized, unorganized or partially organized, compact, dense or dispersed, natural settlement or invaded and sub divided by the land brokers or hired developers (Fig 8, 9, 10).

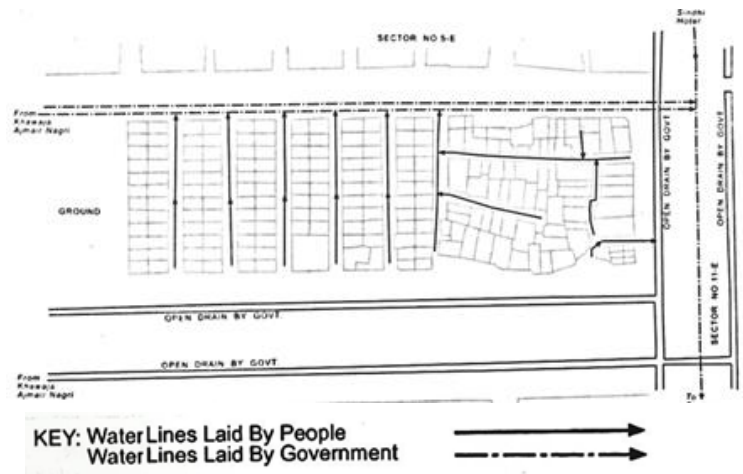

Figure 8 (a): Map of Bilal Colony showing Sewerage lines laid by people and government (Source: OPPRTI, 2002)

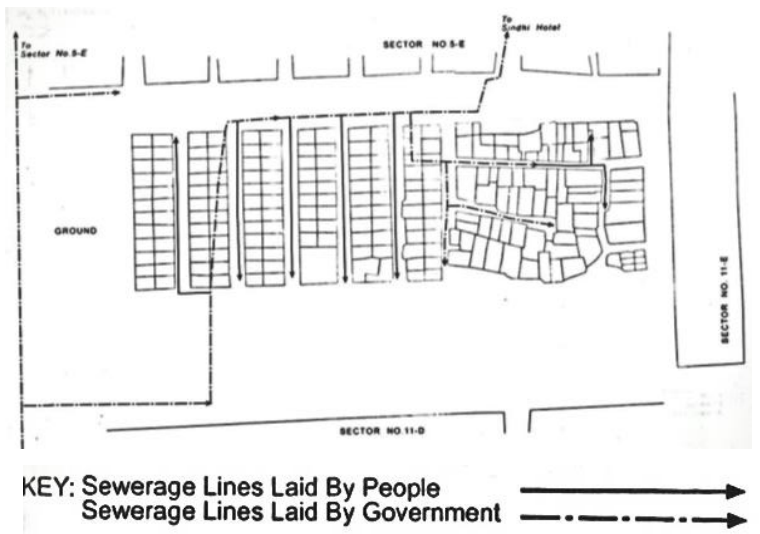

Figure 8 (b): Map of Bilal Colony showing Water Supply lines laid by people and government (Source: OPP-RTI, 2002)

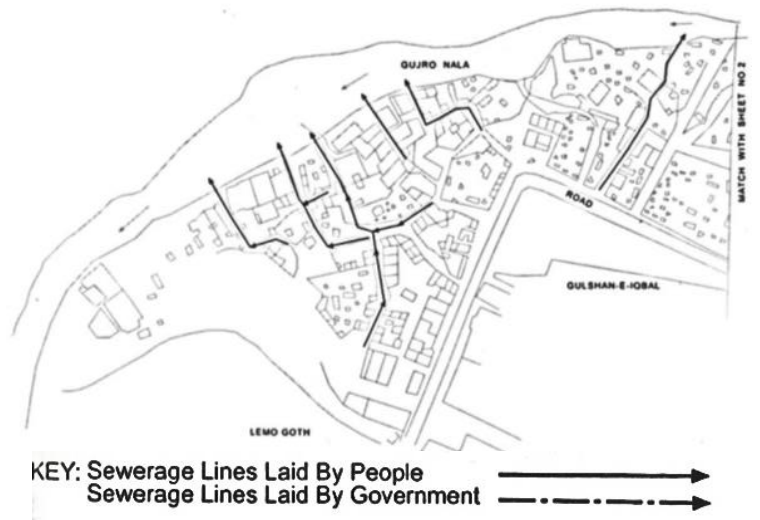

Figure 9: Map of Quaid-e-Azam colony showing sewerage lines by people (Source: OPP-RTI, 2002) 


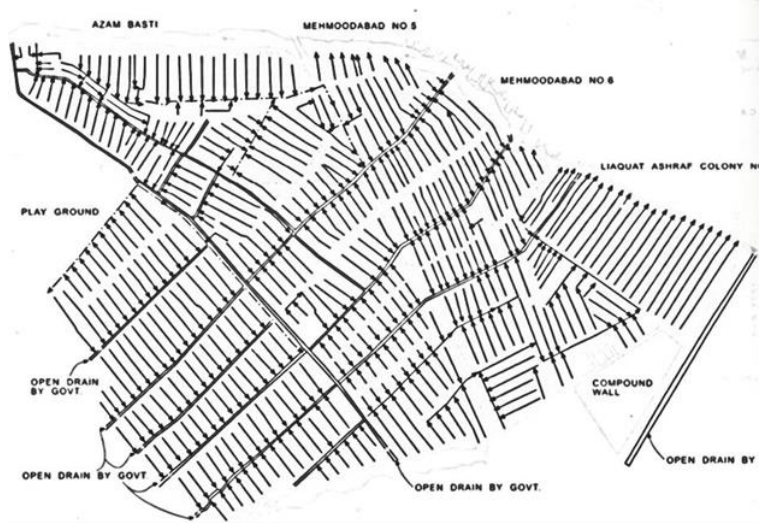

Figure 10: Map of Manzoor Colony showing sewerage lines entirely laid by people on self-help basis (Source: OPP-RTI, 2002)

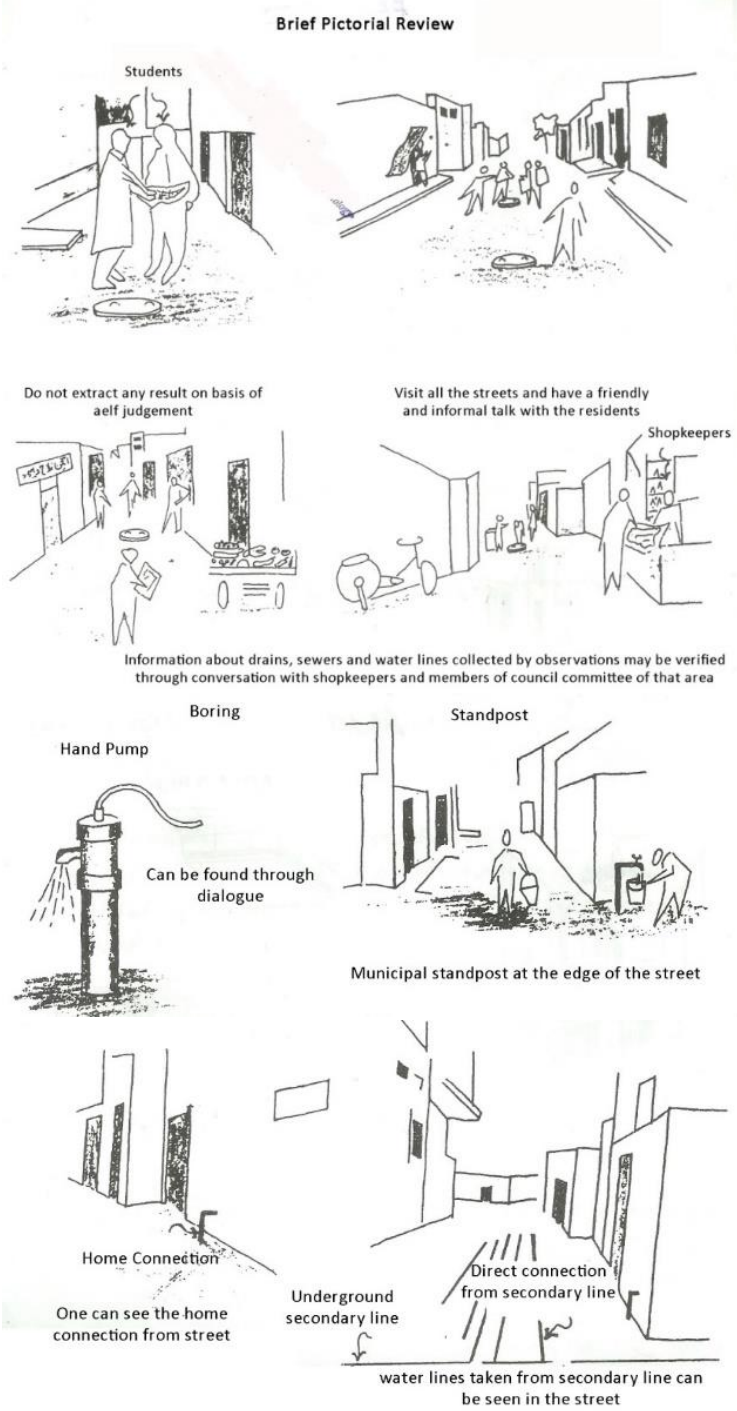

Figure 11: Sketches as guidelines for analyzing the work done by the government or people through visual evidences and interviewing people about them rather than self-assessment or judgment. (Source: OPP-RTI, 2002)
Sketches mentioned in the volume for conducting surveys and documentation of katchi abadis is a guideline of analyzing and accessing the condition on basis of analyzing the work done either by the government or people through visual evidences and interviewing people rather than selfjudgment. Below is the brief pictorial review of guidelines for surveyors.

\subsection{Process of Mapping}

The process of mapping is to document a settlement, village, Goth etc in such a graphical way so as to convey utilized information. In order to locate lanes, houses, schools, clinics in the geographical boundaries of a settlement, a sketch plan is drawn manually to analyze and locate the areas in need of development works. Maps are our eyes like x-ray, they tell us what to do, where to go, who to lobby (Rehman, 2013). Previously all the procedure for conducting mapping was manual. Mapping team of OPP surveyed the areas to be mapped carrying a measuring tape, a compass, small board, paper and basic stationary. To locate north direction they follow sun direction and shadows projection, use compass or ask from a nearby mosque about the qibla (west) direction. From 1994-2008 hand sketches were drawn and refined later. They also update maps acquired from official records of government during the field survey. Lately they were introduced with Google satellite images. Now they trace those satellite images and make further additions as required during field survey and digitize them. Interview respondents informed about the technique of mapping, procedure followed and outcomes obtained. Ashraf Sagar Manager OPP RTI Youth Mapping Team was interviewed about the practice of mapping and its implementation. (See Box-1) 
Box 1: Interview of Mr. Ashraf Sagar

Mapping is to sketch or draw a settlement manually. Through mapping one can acquire a complete picture of a settlement. Providing a map to a community is so productive that people own their place, understand worth of their place and their self-help initiatives to upgrade their habitats. Through this map existence or non-existence of schools, clinics, infrastructure can be located. Community members can negotiate with government on basis of a genuine profile as providing evidence of actual facts that strengthens the claim of a community. It also helps to guide where development works are required.

Sharing the experience of mapping Ashraf Sagar stated; 'The experience of mapping is great since we have acquired a skill. Secondly it is a great feeling that by this effort a number of disadvantaged communities have got their rights to housing and adequate infrastructure needs.

Through this exercise we develop a friendly relationship with community who further helps us in making connection with areas lying next to them. This way we extend the work of mapping'.

Mentioning the shortcomings of this exercise he stated; 'It is a time taking exercise demanding much of the physical efforts that can become easy if modern smart equipment can be acquired and modern techniques can be learnt. But the mapping team is guided by our director that we should spend more time in the community with simple equipment so this strategy may help in developing relationships with the communities as well. Secondly modern equipment is expensive to purchase. We work on 'low cost' policies and provide free of cost maps to communities. We believe on our slain director's (Perween Rahman) slogan of 'zero waste culture' and to work with local resources no matter if they are minimum or scarce.

\subsection{Tangible Outcomes of Mapping}

The existing master plans of government are not updated as fast as communities grow. The areas marked as barren in the official plans were identified later as settlements when mapped. Some tangible and intangible outcomes of mapping extracted through study of various sources of literature are summarized as below;

a. Mapping assists in identification of informal settlements and recognition of those rural villages or Goths that have become areas of urban sprawl.

b. Portraits existing scenario about built infrastructure already present so as to abstain replication of work by the government which is already done by the community through self-help. This way reduces cost effectively and prevents damage to existing services like underground water lines or gas pipelines, telephone lines, electricity supply etc. during further developmental works by the government.

c. Prepares a demonstration of community work on self-help basis and their significance while strengthening the claim of the community towards state to support their efforts by joining hands with them in terms of financial, technical and social support.

d. Map as a tangible evidence of number of houses and families residing in an area prevents from threat of forceful eviction by taking lease or stay order till the time resettlement, compensation, relocation or any acceptable substitute is provided.

e. As a guideline for planning and implementing development works such as water supply, sanitation facility etc., which also raises value of their property.

f. The tool of mapping as a training activity of skill and medium of knowledge helps in carrying more informed, effective and 
formal negotiation with government officials regarding development works in katchi abadis.

g. Cost estimation and expenditure becomes easier to calculate.

h. Through mapping exact demarcation of various vacant land parcels of clear or unclear ownership may refrain unlawful authorities and land grabbers from illegal land invasion, subdivision and supply.

\subsection{Intangible Outcomes of Mapping}

In context of problems existing in katchi abadis Perween Rahman (2004) stated several problems and proposed solutions to them. Regarding need of mapping documentation she stated; 'lack of maps documenting the existing system leading to (1) a lack of transparency in management and (2) ad-hoc development'.

a. A community once acquiring a map of their area experience sense of ownership and sense of community for taking concern about well-being of their settlement area.

b. Mapping of individual settlements not only provides information required for development works in particular settlement but extends outcomes of this exercise on city wide scale.

c. Local leaders, some of whom previously tried to allocate plots or evict people according to their own whims and interests, are now careful not to alienate residents who now possess a sense of access to authorities they did not previously have (World Bank Evaluation Report, 1982, p 11-4)

\section{Legal Acquisition or Illegal Acquisition of Land? \\ 6.1 Case of Zobu Goth, UC 8, Gadap Town, Karachi}

The case of forceful evictions from Zobu Goth by the government is a significant example of community advocacy through exercising mapping. Zobu Goth faced forceful evictions thrice by the Government in 2007 and 2008 but retained ownership by adopting a successful strategy of organizing themselves and making necessary measures to negotiate with the government functionaries.

An unpublished paper by Aquila Ismail (2009) mentions that witnesses and evidences inform about existence of this settlement as a Goth took place decades ago by migration of low income households to the peripheral boundaries of Karachi due to exponentially increasing land value in central Karachi. They acquired 30 years lease by the District Commissioner (DC). People paid in cash the purchasing cost of their plots however illicit payments to police facilitated the settlement to grow faster. Sometime later, constructions of Northern by pass surprisingly increased the land value of this locality. The acting government at that time, under a false basis of constructing a road, paved an opportunity to acquire these valuable lands and resettle their supporters by reestablishing a settlement named 'Altaf Nagar'. The Goth was bulldozed eventually, the land was took over, divided into plots and sold with KMC stamps at a price 45,000 Rs (US \$ 445) for a 120 sq Yard plot which seemed affordable for lower income group of people looking for shelters on urgent need. In this way, the demolition of 'rural villages' paved the way for the urban poor acquiring land!' (Hasan, 2012) 
Through mobilization by social activists the affecters managed to organize themselves and approached the court for a plea to justice but could not acquire relief for the sake of not having any document of evidence showing land entitlement and demarcation of boundary line of the settlement and people's respective land titles. OPP_RTI helped the targeted community in acquiring these maps and official records as factual evidence which were pretended to be 'lost' in government files. Interview with Salim Aleemuddin (Director OPP) informed about the matter as mentioned in Box 2.

\section{After getting access to maps and official records, contacting political and social}

leaders and activists and involving media; the case became public. Arrival of new government in 2008 also became advantageous in favor of the community who eventually succeeded in achieving security from government and achieved land entitlement for the Goth by BoR (Board of Revenue). Hasan (2012) stated the facts of effective mobilization of the community to establish as an organization, providing awareness of correct information on land demarcation and status, getting an access to the concerned authorities acquiring the documents and preparing maps as to establish true facts as ground realities worked as a successful strategy for the Zobu Goth.

Box 2: Interview with Architect Salim Aleemuddin, Director OPP-RTI

Zobu goth in Gadap Town adjacent to Orangi Town was identified by government as an unofficial settlement, aimed for eviction and demolition several times. Looking into the matter social activists collaborated with Goth elders. It was found people living there since ages had no legal land title and ownership. It was a question how to get the ownership? Since OPP had extensively experiential work with katchi abadis so we knew the process of regularization of katchi abadis. Likewise Goths may also get lease. But there were two problems; first where to go for consultation secondly there was not any evidence of actual facts about number of houses and number of families living there.

Consultation was carried with multiple government agencies concerned with Goths and their population including BOR Board of Revenue. The existing map acquired from Board of Revenues on basis of which the legal proceedings had to be carried was found to be not updated and had certain errors as the number of houses and no of Goths quoted was far less than the existing scenario. Their list was even different from statistics of another agency i.e., Census of Pakistan. Another list from Chief Minister Ghulam Arbab Rahim also did not match with the lists of formerly mentioned agencies. OPP after collecting lists from various official agencies made a comparison, sorted the lists thoroughly, removed doubling and made a refined list. Google satellite images were also considered for verification. By the end there were 2,173 Goths identified on the map. During the identification process of Goths by OPP it was found that nearly all Goths hadn't official entitlement or ownership. Either there wasn't any record or those having the record had no worth since it was expired years back.

Having a map as ground reality could make it easier to apply for stay order from court against this forceful eviction. OPP started mobilizing people to take initiatives for their housing rights. When our team visited the Goth for mapping, to some people it was a matter of surprise and astonishment, to some it was questioning why is it going on and some people showed resistance as they thought it might be to evict them in future. However, the team ultimately convinced majority of people that it is being carried to save them from eviction by enabling them to get ownership and without an accurate map it is not possible to communicate their claim. A copy of the map is also shared with the Goths elders and it is free of cost so this also makes the efforts easier to convince the people. On the basis of communities stand for their housing rights and lobbying with official agencies stay order was approved by the court. Meanwhile 1063 Goths got lease from government for time period of 99 years. 
Further development works in Zobu Goth are under process. OPP-RTI 137th QPR-March 2014 states; Youths of Khairabad/ Zobu Goth are under training. Mapping and planning of housing units is in progress. This initiative has evolved into a technical support unit, the Tameer Technical Centre (TTC).

\subsection{Case of a Goth of UC4, Gadap Town, Karachi}

A Goth of UC 4 of Gadap Town was found to be on continuous threat of eviction. Informed by residents of the Goth, authorities of a corporative housing society who claims to be the owner of the land came several times to bulldoze the settlement but on resistance from the community/ people prevented their settlement from eviction. The Goth faced forceful eviction in 2010 but affected people again constructed their houses. Goth started to become a proper settlement from 2006. However, the Goth activist claimed to have an ownership to this Goth by successive inheritance from his elders who belonged to this land since ages without any proof of evidence. The entire lifestyle of the settlement was transformed altogether as compared to traditional pattern of peri urban Goths. The Goth activist backend by his political support acquired huge tract of land of 65 acres that apparently seemed entirely illegal. Highly organized sub division of the land into plots of various sizes i.e. 120, 240, 400 sq yards, wide streets and purposely leftover spaces for public amenities were observed during a field survey into the Goth. He informed this land subdivision is carried through self-initiatives, taking help of a local mason without any map or plan. Illegal connections from municipal water supply lines, gas lines and electric poles were acquired later. Besides 900 residential dwellings and 500 vacant plots (many as fake allotments was evident) were marked on the map and documents so as to show a sizeable community in order to ease for acquiring lease from government. 98\% people purchase land through their life long investments. Few Interview respondents informed as mentioned in Box 3.

Box 3: Interviews with Community members of Goth in UC 4, Gadap Town Karachi

a. Mauhammed Javed bought a plot of $120 \mathrm{sq}$ yards in 2006 at a cost of 70,000 Rs from Goth activist and spent 4, 00,000 Rs on incremental development of his house residing 5 family members. A local mason made the sketch plan.

b. Muhamad Ayaz Hussain came to this Goth from Punjab in 2008 being unemployed and looking for a job as a worker in factory. He bought 240 sq yards plot for a cost of 20,000 Rs and took incremental development of his nuclear family house residing 3 families. By the time he came to this place there was neither electricity nor Sui gas. They spent their entire savings on their house and do not want to leave this Goth since they do not want to lose the sense of community and belongingness to this place which they achieved in several years.

c. In 2010, flood affectees came to this Goth living in huts and shacks in which 4 families who are relatives of each other are hardly making their both ends meet by working in a nearby factory.

Informed by the activist they have a committee of 11 members to resolve the matters and for the planning and development issues of the Goth which is registered in Social department. The intension was to be organized for unity would assure survival. Moreover the committee charges 10,000 rupees for any further buying or reselling of the plots. Since land possession of this Goth was unofficial and illegal therefore, initially they sold the plots even at a cost of 5000 to 10000 Rs. After 
populating the Goth with sizeable population from various ethnic backgrounds they acquire help from a mapping consultant for making a map to claim for lease from government.

Goth activist stated 'the real beneficial is the government, however they are obliged to NGO's who make maps at nominal price for them in order to apply for the lease processes'. By the time they applied for lease under Goth Abad Scheme they were disappointed since the lease process had been ceased for an uncertain time period. However the Goth is still on threat of eviction.

\section{Conclusion}

The large urban metropolis of Pakistan are evidently growing at a fast pace with explosive population growth. Initially state's policies for providing affordable housing to the urban poor being ineffective showed no further betterment for almost more than 30 years. Inadequate functioning by government agencies in the area of providing adequate housing to its citizens not only indirectly giving way to initiation, formation and propagation of informal settlements on vast sprawling land of unjustified ownership but also political bodies and government functionaries embedded in unjustified land transformation practice must be discouraged. Stated by Joel Brady, 'Land is itself a sacred, living being'.

The unjustified land possession by unofficial means deprive the deserving communities which remain deprive over a long time who eventually struggle for their survival on selfinitiatives. Besides providing technical assistance to underprivileged informal settlements and making effective policies for providing affordable housing to citizens, the need is to assist them with awareness about legal land acquisition procedures and the market of illegal land grabbers in order to save them from unofficial means of acquiring land. Last but not least mapping as a tool of documentation on city wide level especially for peri urban land of unclear status may refrain unlawful authorities and land grabbers from land invasions, sub divisions and selling.

Besides preventing illegal land grabbing and supplying those poor and heavily populated communities who over a considerable time period have struggled to achieve basic services of fresh water supply and sewerage supply on self-initiatives need technical assistance for which on paper graphical documentation is basic requirement. To achieve security of land tenure, social services and public amenities mapping as a demonstration of existing scenario about built infrastructure, number of houses and families residing assists in providing factual evidence for further planning and development works. In this way local leaders of any unlawful authorities become careful not to evict people or illegally allocate plots to other people for their personal gains and interests.

\section{Acknowledgements}

Very special thanks to Ar. Rabia Siddiqui, Assisstant Professor Dawood College of Engineering \& Technology and Siraj Head TTRC for conducting onsite investigation and interviews.

\section{List of Interviews}

Ashraf Sagar, Manager, Youth Mapping OPP-RTI

\section{Salim Aleemuddin, Director OPP-RTI}

Goth activist and community members of a Goth in UC4, Gadap Town, Karachi 


\section{References}

Anwar, N. (2013) Urban Transformations; Brokers, Collaborative Governance and Community Building in Karachi's Periphery, Asia Research Institute, National University of Singapore, Singapore

Hasan, A. (2008) Housing Security and Related Issues; The Case of Karachi

Hasan, A., Raza, M. (2012) Karachi: The Land Issue, Urban Research and Development Cell, NED University Karachi

Ismail, A. (2009) Case of Zobu Goth, An Unpublished Research Paper.

Linden, J. and Selier, F. (1991) Karachi; Migrants, Housing and Housing Policy, Khalid Imran Lahore, Pakistan

OPP-RTI (2002) Katchi Abadis of Karachi; Documentation of Sewerage, Water supply lines, Clinics, Schools and Thallas; Volume One: The First Hundred Katchi Abadis Surveyed, Karachi, Pakistan

OPP-RTI (2014) Orangi Pilot Project; Institutions and Programs 137th Quarterly Report, Karachi, Pakistan

Rahman, P. (2004) Katchi Abadis of Karachi; a Survey of 334 Katchi Abadis, OPP-RTI, Karachi, Pakistan

World Bank (1982), World Bank Evaluation Report, 1982, p.11

Younus, M. (2010) Creating Synergy in the Implementation of Housing Rights; Actions by Government and Civil Society; A Case Study of Karachi Pakistan, Urban Resource Center, Karachi Pakistan.

Retrieved from http://www.urckarachi.org/Housing\%20Situation\%20report.HT 